\title{
HUKUM SEBAGAI PRODUK SEJARAH
}

\author{
Himawan Estu Bagijo
}

Balitbangda bidang Hukum dan Konstitusi Propinsi Jawa Timur

\begin{abstract}
Abstrak
Aturan hukum merupakan produk penyelenggara Negara yang diharapkan dapat menyelesaikan permasalahan, menciptakan keadaan tertentu yang diinginkan oleh pembentuknya. Dalam kerangka berfikir yang demikian, maka situsai dan kondisi yang melatarbelakangi proses terbentuknya aturan hukum mempunyai pengaruh besar atas substansi pengaturannya. Pemikiran tersebut dapat dibuktikan, dengan mengungkapkan berbagai aturan yang pernah ada dalam sistem hukum Indonesia sejak masa kemerdekaan hingga saat reformasi telah digulirkan.
\end{abstract}

Kata Kunci : proses pembentukan hukum, aturan hukum, substansi

\begin{abstract}
The purpose of the rules that compose by the state organ is to solve the problem and create definite situation trough the creator idea. Base on the reason, the background (situation and condition) of law making process will be influence the substance of the output (rules). This idea can be proof by description most of the rules form the beginning of the Indonesian independence till the reformation.
\end{abstract}

Keyword: law making proses, substanceofrules

\section{PENDAHULUAN}

Perjalanan kehidupan hukum di setiap negara tidak dapat dilepaskan dari dinamika kehidupan berbangsa dan bernegara secara menyeluruh. Seperti diungkapkan oleh Harold J. Berman tentang sistem Hukum Eropa yang disebut sebagai "western legal tradition", dinyatakan "it is necessary to recognize that law in West is formed into integrated legal system, in each of which the various constituent elements take their meaning partly from the legal system as a whole" (Berman, 1995;11). Untuk memahaminya tidak dapat hanya membaca teks itu saja, tetapi juga harus melihat dalam konteks yang bagaimana hukum itu dibentuk. Namun demikian, mempelajari sejarah hukum tidak bermaksud untuk memberi pembenaran (justify) tetapi dimaksudkan untuk mengatakan suatu kebenaran (truth). Kebenaran ini harus dianalisis apakah sesuatu tepat atau tidak, dengan kata lain untuk menyatakan boleh dan atau tidak bolehnya sesuatu terjadi pada konteksnya. Dalam kaitannya dengan sejarah hukum Indonesia, terdapat dua buku penting yang ditulis oleh John Ball berjudul Indonesian Legal History 16021848, Oughtershaw, Sydney, 1982, dan Indonesian Legal History British West 
Sumatra, 1685-1825, Oughtershaw, Sydney, 1984.

Pada saat bangsa Indonesia memproklamirkan diri menjadi sebuah bangsa yang merdeka, dimulailah tata kehidupan hukum Indonesia yang berdasar pada Proklamasi Pemerdekaan Indonesia dan UUD 1945 sebagai hukum dasar tertulisnya. Proklamasi dinyatakan sebagai sebuah tertib hukum karena proklamasi menetapkan sebuah negara baru yang memiliki kedaulatan atas wilayah negara. UUD 1945 dinyatakan sebagai hukum dasar tertulis, karena UUD 1945 menjadi landasan konstitusional penyelenggaraan negara.Berdasar UUD 1945 berbagai proses bernegara diatur dan diberikan landasan hukum yang bersifat dasar.

Sebagai contoh, yaitu lembaga Majelis Permusyawaratan Rakyat (MPR). Dalam UUD 1945 (sebelum amandemen) diatur adanya organ negara yang diberi nama Majelis Permusyawaratan Rakyat (selanjutnya disebut MPR). Kewenangan MPR ditetapkan sebagai berikut : (a)Pasal 1 ayat (2) “Kedaulatan adalah di tangan rakyat dan dilakukan sepenuhnya oleh Majelis Permusyawaratan Rakyat"; (b)Pasal 3 "Majelis Permusyawaratan Rakyat menetapkan Undang-Undang Dasar dan garis-garis besar daripada haluan negara"; (c)Pasal 6 ayat (2) "Presiden dan Wakil Presiden dipilih oleh Majelis Permusyawaratan Rakyat dengan suara yang terbanyak"; (d)Pasal 37 ayat (1) "Untuk mengubah Undang-Undang Dasar sekurang-kurangnya 2/3 daripada jumlah anggota Majelis Permusyawaratan Rakyat harus hadir. Ayat (2) "Putusan diambil dengan persetujuan sekurang-kurangnya $2 / 3$ daripada jumlah yang hadir.

Menggunakan pendekatan sejarah ketatanegaraan Indonesia, maka dapat dikemukakan, bahwa pelaksanaan Pasal-pasal yang disebut diatas mengalami pasang surut yang sangat luar biasa. Misalnya kewenangan MPR untuk memilih Presiden dan Wakil Presiden, maka untuk pertama kali justru dilakukan oleh lembaga lain yaitu Panitia Persiapan Kemerdekaan Indonesia (lihat Pasal III Aturan peralihan UUD 1945 sebelum amandemen). Hal ini dapat diterima secara logis, karena pada saat itu MPR belum terbentuk, dan pemerintahan harus segera menjalankan fungsinya. Oleh sebab itu, pemerintahan harus ada dan tidak perlu menunggu terbentuknya MPR hasil pemilihan umum. Disisi yang lainnya,kewenangan MPR untuk melakukan perubahan atas UUD 1945 pun tidak pernah dipergunakan sampai tahun 1988. Hal ini disebabkan karena keinginan sosial politik dari MPR belum menghendaki perubahan. Tentang 
keinginan Politik melakukan perubahan UUD 1945 ini dapat dianalisis dalam Pasal 105 dan 107 Ketetapan MPR RI No. I/MPR/Tahun 1983 tentang Tata Tertib MPR, yang menentukan keinginan politik MPR untuk mempertahankan UUD 1945 dan bermaksud melaksanakan secara murni dan konsekwen. Selanjutnya perihal perubahan UUD 1945 ini diatur dalam Ketetapan MPR RI No. IV/MPR/1983 tentang Referendum dan UU No. 5 Tahun 1985 tentang Referendum yang materi muatannya justru memperulit perubahan UUD 1945. Hal ini berbeda ketika pada tahun 1999, MPR yang didukung oleh kondisi sosial politik justru melakukan berbagai perubahan atas UUD 1945 hingga empat kali perubahan.

Hal tersebut diatas berbeda dengan pada saat perkembangan ketatanegaraan Republik Indonesia memasuki paruh kedua berlakunya UUD 1945 berdasarkan Dekrit Presiden 5 Juli 1959. Seri kedua dari konsep bernegara berdasar UUD 1945 memasuki tahap yang lebih kompleks. Kompleksitas bernegara pada tahap kedua ini telah dipengaruhi oleh berbagai faktor, baik sosial, ekonomi maupun politik. Demikian pula berbagai ketentuan hukum seperti Undang-undang Pokok Agraria, Undang-undang Pemerintahan Daerah, Ketetapan MPR tentang GBHN dan perundang-undangan tentang HAM merupakan refleksi dari zamannya.

Tulisan singkat ini mencoba menganalisis berbagai produk hukum yang ada dalam praktek ketatanegaraan dengan pendekatan sejarah hukum. Ketentuan hukum yang disebut dalam makalah ini dianalisis dan dikemukakan sebagai contoh keterkaitan antara sejarah dengan hukum. Untuk mempermudah uraian, maka aturan hukum yang dianalisis adalah ketentuan hukum pada masa Indonesia merdeka hingga saat ini.

\section{Hukum di awal Indonesia Merdeka.}

Untuk menjelaskan apa dan bagaimana terjadinya berbagai ketentuan hukum di awal Indonesia merdeka, pemikiran Mazhab Sejarah (historis) yang berkembang di Jerman dapat dipergunakan sebagai landasan berpikir. Mazhab historis ini merupakan sebuah reaksi tertentu terhadap dua kekuatan yang berkuasa dari zamannya, yaitu : (1) rasionalisme dari abad ke-18 dengan kepercayaannya kepada hukum alam, kekuasaan akal dan prisip-prinsip pertama, yang semuanya dikombinasikan untuk meletakkan suatu teori hukum dengan cara deduksi dan tanpa memandang fakta historis, berciri khas nasional dan sesuai dengan kondisi masyarakatnya. Seperti dikemukakan oleh G.W. Paton "The historical school 
in part was a result of that surge of nationalism that arose at the end of the eighteenth century" (Paton,1972;19); (2) kepercayaan dan semangat revolusi Perancis dengan pemberontakannya terhadap kekuasaan dan tradisi, kepercayaannya pada akal dan kekuasaan kehendak manusia atas keadaan-keadaan, dan pesan-pesan kosmopolitannya.

Mazhab historis merupakan bentuk penolakan atas pemikiran hukum alam. Disisi lain juga menyatakan bahwa hukum sebagai produk lembaga legislative pada dasarnya merupakan bentuk kesewenang-wenangan, namun hukum berkembang sebagai bentuk respon yang bersifat impersonal serta ditemukan dalam semangat masyarakat suatu bangsa, hal ini dikemukakan oleh Lloyd's Freeman, sebagai berikut "Savigny rejected natural law....Law was not the result of an arbitrary act of legislator but developed as response to the impersonal powers to be found in the people's national spirits" (Hamstead, 1985;868).

Berbeda dengan apa yang terjadi di Jerman, yang terjadi di Indonesia ketika awal kemerdekaan. Apa yang terjadi di Jerman saat itu justru sebaliknya dengan yang terjadi di Indonesia. Hukum di awal kemerdekaan secara luas justru berafiliasi pada karakter hukum civil law sistem dengan salah satu sistemnya, yaitu kodifikasi hukum. Seperti dikemukakan oleh Satjipto Rahardjo "tipe hukum dari negara jajahan tidak akan jauh dari tipe hukum penjajah". Secara lengkap pendapatnya adalah "kemerdekaan merupakan proses yang berisi difusi nilai-nilai, norma-norma, keyakinan-keyakinan dan pranatapranata sosial secara kultural dan struktural menyebabkan organisasi dari negara-negara jajahan itu mirip dengan pengorganisasian dari negara-negara Barat, yang dalam hal ini bisa disebut sebagai susunan modern". (Satjipto Rahardjo, 1986;32).

Pemikiran di atas nampak jelas jika dicermati dalam politik hukum yang ditertuang dalam UUD 1945. Jika dianalisis, maka garis politik hukum dalam UUD 1945 tidak diarahkan pada aspek materi hukum dan bentuk hukum, melainkan pada Kedaulatan Hukum(supremasi hukum), Rechtsidee (cita-cita hukum) dan ketentuan Pasal II Aturan Peralihan. Ide Hukum Nasional yang hendak diwujudkan melalui UUD 1945 adalah: ide pengayoman; ide keadilan sosial, ide demokrasi, ide Ketuhanan dan Kemanusiaan. (Marsilam Simanjuntak, 1997;12).

Politik hukum melalui Pasal II Aturan Peralihan, pada dasarnya merupakan komitmen pada pandangan sistem civil law, yaitu diperlukannya hukum tertulis dalam penyelesaian 
persoalan hukum, maka dengan berlakunya Pasal II Aturan Peralihan, kekhawatiran kekosongan hukum tidak akan terjadi. Berdasar pemikiran ini maka berlakunya hukum barat (misalnya Wetboek van Straafrecht (KUHP) dan Burgerlijk Wetboek (KUH Perdata)) diterima sebagai sebuah konsekwensi logis. Akibat dianutnya pemikiran Pasal II Aturan peralihan tersebut, maka pembentukan hukum yang berakar pada budaya bangsa terabaikan. Disisi lain, hukum barat yang terkodifikasi dalam KUH Pidana dan KUH Perdata justru menjadi hukum positip yang harus diterima. Terhadap KUH Pidana, terdapat permasalahan teoretik terkait dengan tidak adanya terjemahan resmi yang dibuat oleh negara. Dalam praktek terjadi perbedaan penggunaan buku KUH Pidana terjemahan (Moeljatno, Andi Hamzah, Soesilo, dll). Akibatnya setiap penegak hukum dapat secara bebas menggunakan buku hukum tersebut, yang notabene memiliki perbedaan terjemahan. Namun demikian, juga tidak mungkin menerapkan Wetboek van Straafrecht (WvS) sebagai hukum positip. Hal ini terkait dengan dua alasan, bahwa WvS ditulis dalam bahasa Belanda, maka tidak mungkin hal ini dapat dikuasai secara baik oleh orang Indonesia. Sementara itu, berdasar ketentuan Pasal 36 UUD 1945, bahasa nasional adalah bahasa Indonesia, maka hukum nasional pun harus dirumuskan dalam bahasa Indonesia.

Situasi di atas pada dasarnya dapat dipersamakan dengan berlakunya prinsip resepsi (penerimaan) hukum seperti pada sistem hukum Romawi yang dikembangkan oleh para sarjana yang studi hukum di Universitas Bologna. Melalui Universitas Bologna, muncullah diskursus ilmiah tentang hukum pada tataran hukum positip,yang dalam dinamikanya melahirkan berbagai disiplin hukum. (Bernard Arief Sidharta, 2000; 11).Para sarjana tersebut kembali ke negara masing-masing dengan membawa nilai-nilai hukum positip Romawi (Codex de Justitianus). Oleh sebab itu, prinsip resepsi hukum ini di satu sisi dianggap telah mengabaikan berlakunya emansipasi hukum dari nilai-nilai yang sifatnya mengakar pada budaya hukum. Sikap penolakan berlakunya prinsip resepsi hukum ini ditunjukkan secara tegas oleh Von Savigny dengan konsepsi "hukum adalah jiwa bangsa" (volk geist).

Jauh sebelum para ahli hukum Jerman mengemukakan inti pemikiran dari mazhab historis, Edmund Burke, telah merumuskan kepercayaan pokoknya akan politik dan filsafat. Ia mencemoohkan usaha untuk menyusun suatu konstitusi atas dasar prinsip- 
prinsip abstrak, dan menegaskan bahwa itu hanya dapat dihasilkan oleh perkembangan bertahap dan organis. Hugo juga menekankan pada unsur-unsur irrasional yang ada pada tiap badan hukum, yang terikat untuk mengurangi pentingnya konsepsi-konsepsi hukum dan mempertimbangkan pembuatan peraturanperaturan. Seperti dikemukakan oleh J.J.H. Bruggink "Hukum sebagai sebuah sistem merupakan produk suatu kesadaran hukum, yang berarti bahwa sistem hukum juga mengandung hal-hal yang irrasional, namun demikian karena hukum terjadi karena membentuk suatu keseluruhan yang saling berkaitan, maka aspek rasionalnya yang lebih menonjol (J.J.H. Bruggink, 1999;137). Sesuai uraian tersebut, maka alasan nyata yang melahirkan tesis mazhab historis, adalah persoalan kodifikasi hukum Jerman sesudah perang-perang Napoleon (W. Friedmann, $1990 ; 60$ )

\section{Hukum di Masa Pemerintahan Soekarno.}

Pemerintahan Soekarno memasuki babagan baru ketika Dekrit Presiden diumumkan pada tanggal 5 Juli 1959. Dinyatakan sebagai babagan baru, karena selama menjadi Presiden Indonesia, Soekarno tidak pernah bertindak sebagai kepala negara dan kepala pemerintahan secara bersamaan dalam kondisi memerintah. Hal ini disebabkan karena pada tahun 1945-1948, Soekarno masih harus memasuki kondisi perang mempertahankan kemerdekaan. Selanjutnya tahun 1948-1959 berdasar Konstitusi RIS dan UUD Sementara 1950 Soekarno hanya bertindak sebagai kepala negara, sedang kepala pemerintahan berada di tangan perdana menteri.

Dekrit Presiden 5 Juli 1959 merupakan sebuah bukti sejarah dari sebuah produk hukum berupa keputusan presiden (sebagai penguasa eksekutif) yang mampu menerobos semua lapisan produk hukum yang lebih tinggi. Keputusan Presiden tersebut bahkan mampu membingkai berlakunya kembali UUD 1945. Berdasar Keputusan Presiden tentang Dekrit itu pula muncullah berbagai TAP MPRS yang substansinya bermasalah, seperti : (a) TAP MPRS No. I/MPRS/1960 tentang Manifesto Politik Indonesia sebagai Garis-garis Besar daripada Haluan Negara; (b)TAP MPRS No. III/MPRS/ 1963 tentang Pengangkatan Pemimpin Besar Revolusi Indonesia Bung Karno Menjadi Presiden Republik Indonesia Seumur Hidup; (c)TAP MPRS No. IX/ MPRS/1966 tentang Surat Perintah Presiden/Panglima Tertinggi Angkatan Bersenjata Republik Indonesia /Pemimpin Besar Revolusi/Mandataris Majelis Permusyawaratan Rakyat 
Sementara Republik Indonesia.

Tiga ketetapan di atas hanya sebagai contoh dari produk MPRS masa itu yang jika dianalisis berdasar ketentuan UUD 1945 sangat bertentangan. TAP MPRS No. I, pada dasarnya merupakan bentuk penundukan posisi MPRS terhadap Presiden Mandataris. Hal ini dibuktikan dengan penempatan bahan pidato Presiden yang berjudul "Penemuan Kembali Revolusi Kita" sebagai materi pokok GBHN masa itu. TAP MPRS No. III, secara substansial bertentangan dengan ketentuan Pasal 7 UUD 1945, yang mengatur masa jabatan Presiden 5 tahun dan dapat dipilih kembali. Semenara itu, TAP MPRS No. IX, secara substansial merupakan TAP MPRS yang berlebihan, hal ini disebabkan karena materi muatan TAP tersebut hanya berasal dari sebuah Keputusan Presiden tentang Surat Perintah Sebelas Maret.

Ketentuan-ketentan hukum di atas dapat dikategorikan sebagai bentuk refleksi dari budaya hukum yang berkembang saat itu. Meskipun secara konstitusional dapat diputuskan sebagai bentuk kesalahan konstitusional, namun dalam praktek pun hal itu diterima sebagai sebuah kebenaran.

Berbagai keputusan hukum lain yang merupakan refleksi dari kondisi masyarakat pada saat itu, yaitu :
(a)Perubahan lambang lembaga peradilan dari Dewi Yustitia menjadi pohon beringin. (Dewi Yustitia dianggap barat dan liberal, sementara Pohon Beringin lebih bersifat naturalis pada nilai dasar bangsa Indonesia); (b)Penolakan berlakunya BW sebagai aturan hukum, dan hanya menjadikannya sebagai buku hukum/pedoman. (Aturan dalam BW dianggap tidak sejalan dengan nilai-nilai hukum adat, oleh sebab itu para hakim harus menggali nilai-nilai hukum adat dalam memutuskan perkara): (a)Pembentukan UU No. 5 Tahun 1960 tentang Undang-undang Pokok Agraria yang dianggap sebagai kesepakatan masyarakat dalam mensikapi berlakunya hukum barat tentang Tanah di Indonesia (Ahmad Sodiki, 2001;75-88). Penggantian itu merupakan finalisasi atas kesepakatan menghilangkan pengaruh hukum barat dalam hukum pertanahan di Indonesia (Soetandyo Wignjosoebroto, 1998;78). Berbagai bentuk kebijakan hukum yang dilakukan oleh pemerintah Soekarno pada dasarnya dapat disimpulkan sebagai bentuk emansipasi dan partisipasi aktif dari masyarakat untuk mengikis berlakunya hukum barat. Pemikiran tentang upaya menghilangkan pengaruh barat terhdap hukum juga dikemukakan oleh Roeslan Abdulgani "hendaknya kita sekalian dalam mengabdikan diri kepada ilmu hukum 
serta parkatek-pertumbuhan dan perkembangannya selalu berdiri tegak atas dasar Pancasila kita, tidak hanya sebagai "Weltanschauung" serta "Lebensanchauung" kita bersama, melainkan juga selaku sumber moral, isi moral dan "Way of life", selaku pedoman hidup, yang bermoral dan beretika....", (Roeslan Abdulgani, tanpa tahun;14). Secara tidak langsung, pembentukan hukum itu merupakan bentuk perlawanan terhadap kokohnya tatanan hukum barat yang telah berlaku. Sikap perlawanan terhadap kemapanan hukum barat ini dapat dikategorikan sebagai bentuk emansipasi/partisipasi. Hal ini sejalan dengan pemikiran Savigny sebagai tokoh Mazhab Historis, sebagai berikut : (a)hukum ditemukan tidak di buat. Ada pandangan yang pesimistis tentang perbuatan manusia. Pertumbuhan hukum pada dasarnya adalah proses yang tidak disadari dan organis; oleh karena itu perundang-undangan adalah kurang penting dibandingkan dengan adat kebiasaan; (b)Karena hukum berkembang dari hubungan-hubungan hukum yang mudah dipahami dalam masyarakat primitif ke hukum yang lebih kompleks dalam peradaban modern, kesadaran umum tidak dapat lebih lama lagi menonjolkan dirinya secara langsung, tetapi disajikan oleh para ahli hukum, yang merumuskan prinsip-prinsip hukum secara teknis. Tetapi ahli hukum tetap merupakan suatu organ dari kesadaran umum, terikat pada tugas untuk memberi bentuk pada apa yang ia temukan sebagai bahan mentah. Perundang-undangan menyusul pada tingkat akhir, oleh karena itu ahli hukum sebagai badan pembuat undang-undang relatif lebih penting dari pada pembuat undang-undang; (c)Undang-undang tidak berlaku atau dapat di terapkan secara universal. Setiap masyarakat mengembangkan hukum kebiasaannya sendiri, karena mempunyai bahasa, adat istiadat dan konstitusi yang khas. Savigny menekankan bahwa bahasa dan hukum adalah sejajar. Juga tidak dapat diterapkan pada masyarakat lain dan daerah-daerah lain. Volkgeist dapat dilihat dalam hukumnya; oleh karena itu sangat penting untuk mengikuti evolusi Volkgeist melalui penelitian hukum sepanjang sejarah. (W. Friedmann, 1990;61)

\section{Hukum di Masa Pemerintahan Soeharto.}

Perkembangan hukum pada masa pemerintahan Soeharto berlatarbelakang jatuhnya kekuasaan Soekarno dalam tampuk pemerintahan yang disebut Orde Lama. Kejatuhan Soekarno tidak dapat dilepaskan dari kekuatan sosial politik pada era itu yang mem- 
peroleh dukungan kuat dari Angkatan Bersenjata Republik Indonesia, khususnya angkatan Darat. Seperti dinyatakan oleh Indria Samego "Siapa pun tidak dapat mengingkari kenyataan bahwa ABRI mempunyai peran yang cukup sentral dalam sejarah politik Orde Baru pada khususnya dan proses pembentukan negara (state formation) Republik Indonesia pada umumnya" (Indria Samego, 1998;16).

Untuk mempermudah analisis atas sejarah hukumnya, maka uraian akan dikhususkan pada substansi Ketetapan tentang Garis-garis Besar Haluan negara (GBHN), khususnya pada kebijakan pembanguan hukum. Seperti diketahui, bahwa TAP tentang GBHN merupakan kerangka dasar semua proses pembangunan yang dilakukan di Indonesia. Untuk melengkapi uraian, maka akan disebut beberapa aturan hukum setingkat UU yang merefleksikan kemauan politik penguasa dalam menata pembangunan hukum pada saat itu.

Pembangunan hukum melalui GBHN tidak dapat dilepaskan dari prinsip Tri Logi Pembangunan yang dicanangkan : Stabilitas, Pertumbuhan dan Pemerataan. Tiga pilar prinsip kebijakan pembangunan ini menjadi dasar penyelenggaraan pembangunan di segala bidang. Demikian juga sejarah pembangunan hukum yang terjadi pada saat itu tidak dapat dilepaskan dari pilar utama tersebut.

Secara penempatan pengaturan, pembangunan hukum dalam GBHN dapat dikelompokkan dalam dua kategori: hukum sebagai sektor dan hukum sebagai bidang. Pembangunan hukum sebagai sektor dapat ditemukan dalam GBHN Tahun 1973-1993, khusus tentang pembentukan undang-undang hanya sedikit, dalam kurun waktu satu tahun rata-rata $5 \mathrm{~s} / \mathrm{d} 10$ undang-undang, yang merupakan bagian dari bidang politik, Aparatur Pemerintahan, Hukum, Penerangan dan Media Massa, Hubungan Luar Negeri. Hal ini berarti bahwa, pembangunan hukum tidak berdiri sendiri secara anggaran, karena menjadi bagian dari pembangunan bidang tersebut. Pembangunan hukum sebagai bidang yang berdiri sendiri tercantum dalam GBHN 1998. Berdasar anggaran Tahun 1998, pembentukan hukum, khususnya pada tingkat undang-undang menjadi sangat produktif, bahkan tercatat sangat luar biasa, pada tahun 1999 diundangkan sebanyak 56 UU, maka rata-rata dalam satu bulan $4 \mathrm{UU}$. Jika dibandingkan dengan sejarah pembentukan UU sebelumnya, maka tahun-tahun itu memang sangat luar biasa, dan mungkin tidak akan pernah terjadi ditahun-tahun mendatang. Oleh 
karena menjadi bidang, maka secara anggaran pembangunan hukum harus memiliki kemandirian dalam pembiayaan.

Jika dianalisis dari isi rencana pembangunan hukumnya, terdapat berbagai ragam penekanan sebagai berikut: (1)GBHN 1973, Dasar Hukum : TAP MPR RI No. IV/MPR/1973 tentang Garis-garis Besar Haluan Negara. Kebijakan pembangunan substansi yang sasarannya adalah Pembaharuan hukum atas dasar kodifikasi dan unifikasi hukum; (Kodifikasi dan unifikasi substansi hukum adalah ciri dari hukum modern yang positivistik, oleh sebab itu, peran negara/penguasa dalam mengartikulasi hukum akan kuat. Akibatnya, nilai-nilai kearifan lokal yang bersifat plural akan sedikit terabaikan. Pembangunan materi hukum banyak diarahkan pada pembangunan hukum ekonomi, yaitu hukum positip. Seperti dikemukakan oleh John Austin tentang "law as command of the authority organ" dan H.L.A. Hart tentang "Primary Rules" and "Secondary Rules") (Charles Sampford, 1989;28-36). Jadi positivisme pada dasarnya memantapkan peran penguasa, yaitu rasionalisme penguasa dalam melihat kebutuhan hukum yang memberikan dukungan pada penciptaan stabilitas Negara; (2)Dasar Hukum : TAP MPR RI No.
IV/MPR/1978, TAP II/1983, TAP II/ 1988 tentang Garis-garis Besar Haluan Negara. Kebijakan pembangunan substansi yang sasarannya adalah Pembaharuan hukum atas dasar kodifikasi dan unifikasi hukum; membina penyelenggaraan bantuan hukum; terwujudnya Peradilan Tata Usaha Negara; penyusunan UU tentang HAM; (3)GBHN 1993. Dasar hukum : TAP MPR RI No. II/MPR /1993 tentang Garis-garis Besar Haluan Negara. Pembangunan Materi Hukum berupa program Legislasi Nasional, mengganti aturan kolonial. Perencanaan hukum berupa : Pembentukan Hukum, Penelitian dan Pengembangan Hukum, Jaringan dokumentasi dan informasi hukum. Pembangunan Aparatur Hukum berupa : peningkatan kemampuan dan profesionalisme, keteladanan Aparat. penerapan Hukum dengan lugas dan tegas, peningkatan peran dan organisasi hukum, lembaga hukum, profesi hukum; Pembangunan Sarana dan Prasarana Hukum.

Secara lengkap Politik Hukum perundang-undangan digariskan dalam GBHN 1993, didasarkan pada tiga prinsip, yaitu : (1)Pemerintahan yang kuat (strong government); (2)Tanggung jawab pemerintah untuk menyelenggarakan pembangunan ekonomi; (3)Pemeliharaan perdamaian, ketertiban dan stabilitas. (Philipus M. Hadjon, 
1996;1).

Uraian di atas menggambarkan betapa statisnya pembangunan hukum yang dilaksanakan pada kurun waktu tersebut. Hal ini disebabkan karena pembangunan hukum lebih banyak diarahkan untuk memebrikan dukungan pada pembangunan ekonomi. Dalam kurun waktu tersebut hukum yang dibentuk lebih banyak pada aturan yang membatasi kebebasan politik warga negara. Sifat pengaturan yang diatur pun lebih bersifat memaksa. Oleh Zelsnick dan Nonet, pembentukan aturan yang demikian disebut sebagai "represif law". Secara lengkap pemikiran Zelsnick dan Nonet sebagai berikut : "In its most distinct and systematic from repressive law displays the following characteristic": Legal institutions are directly accessible to political power; law is identified with the state and subordinated to raison d'etat. The conservation of authority is an overriding preoccupation of legal officialdom. In the "official perspective" that ensues the benefit of the doubt goes to the system and administrative convenience weights heavily. Specialized agencies of control, such as the police, become independent centers of power; they are isolated from moderating social contexts and capable of resisting political authority. A regime of "dual law" institutionalizes class justice by consolidating and legitimating patterns of social subordination. The criminal code mirrors the dominant mores; legal moralize prevails. (Philippe Nonet dan Philip Selznic, 1978;33)

Beberapa ketentuan hukum berbentuk undang-undang yang disebut berikut ini dapat dijadikan contoh konkret sifat represif dari ketentuan hukum pada masa itu, yaitu: (a)Undangundang Nomor 1 Tahun 1970 tentang Ketentuan Pokok Kekuasaan Kehakiman; (b)Undang-undang No.3 Tahun 1975 jo. UU No. 3 Tahun 1985 tetang Partai Politik dan Golongan Karya; (c)Undang -undang Nomor 4 Tahun 1975 jis. UU No.1/1980,UU No.2/1985 tentang Pemilihan Umum; (d)Undang-undang Nomor 5 Tahun 1974 tentang Pemerintahan Daerah; (e)Undang-undang No. 8 Tahun 1985 tentang Organisasi Massa; (f) Undang Nomor 2 Tahun 1988 tentang Sistem Pendidikan Nasional.

Jika dianalisis dengan menggunakan pemikiran Santos, maka pada kurun waktu tersebut diatas dapat dikategorikan sebagai bentuk (prototipe) dari konsepsi positivisme yang pararel dengan prinsip kapitalisme modern. Pada dasarnya prinsip positivisme hukum adalah upaya sadar untuk menciptakan kepastian hukum, muara akhirnya adalah perlindungan atas kepentingan pemilik modal. Karena 
hukum yang berkepastian itu akan memberikan rasa aman dan nyaman bagi kepentingan pengembangan usaha yang berhasil modal (Boaventura De Sousa Santos, 1995;57). Terhadap periodesasi yang dikemukakan Santos, pada dasarnya pararel dengan pemikiran Nonet dan Zelsnick, yang dikonstruksi dalam tiga tataran pembangunan hukum "Represif Law, Otonomous Law, dan Responsif Law". Dalam kategori tersebut, maka pembangunan hukum positip di Indonesia pada akhirnya harus menuju pada tahap pembangunan hukum yang responsive sebagaimana dijelaskan berikut.

Periode 1998, Hukum sudah ditempatkan sebagai Bidang tersendiri, dengan demikian pembangunan hukum bersifat mandiri. Sisi lain adalah cukup tersedianya dana untuk pembangunan hukum ini. Hasil dari perubahan ini adalah : terbentuknya \pm 84 UU selama tahun 1998-2000. (68 UU pada masa Habibi). Kuantitas undang-undang ini terlepas dari kualitas substansi.

Glasnot dan perestroika serta era Globalisasi memberikan pengaruh besar terhadap pemikiran pembangunan hukum di Indonesia. Dalam pemikiran John Nisbit, globalisasi tidaklah sekedar diartikan sebagai kecenderungan dari ekonomi nasional ke ekonomi dunia tetapi juga mencakup sepuluh kecen- derungan (megatrend), yang meliputi : (a)dari masyarakat industri ke masyarakat informasi; (b)dari tehnologi buatan ke tehnologi canggih; (c)dari ekonomi nasional ke ekonomi dunia; (d)dari pandangan jangka pendek ke pandangan jangka panjang; (e)dari sentralisasi ke desentralisasi; (f)dari bantuan kelembagaan menjadi bantuan mandiri; (g)dari demokrasi perwakilan ke demokrasi partisipatif; (h)dari hubungan hirarkhi ke hubungan jaringan kerjasama; (i)dari Utara (negara maju) ke Selatan (negara berkembang); (j)dari pilihan alternatif ke opsi berganda. Secara karakteristik, pembangunan hukum di Indonesia tipenya bergerak pada pola yang Otonom dan Responsif (Phillipe Nonet dan Philip Zelsnick, 1978;53). Hukum dibangun dan disusun untuk kepentingan tujuan hukum yaitu kepastian dan keadilan. Selain itu hukum sudah harus mampu menjawab setiap perubahan yang ada dalam masyarakat.

Fakta lain yang membuktikan tipe hukum yang responsive adalah terbentuknya undang-undang berikut: (a)Undang-undang Nomor 2 Tahun 1998 tentang Partai Politik; (b)Undangundang Nomor 3 Tahun 1998 jo UU no. 12 tahun 2003 tentang Pemilihan Umum; (c)Undang-undang Nomor 9 Tahun 1998 tentang Kebebasan berpendapat di tempat Umum. 


\section{Produk Hukum Pasca Reformasi 1998}

Bagian akhir dari tulisan ini secara tematik tidak lagi menunjuk pada rezim penguasanya. Hal ini disebabkan karena, pasca kekuasaan Soeharto, para pimpinan negara tak lagi dapat bertindak absolut karena pengaruh reformasi yang telah bergulir. Pelaksanaan wewenang Presiden terbatasi secara normatif oleh hasil amandemen UUD 1945 dan peran DPR menjadi lebih kuat dalam menjalankan fungsi pengawasan.

Penataan jenis dan substansi aturan hukum sebagai perwujudan keinginan politik pada masa pasca reformasi dimulai dengan amandemen UUD 1945. Berbagai undang-undang yang dibentuk pun dimaksudkan untuk memberi dasar penguatan pelaksanaan pemerintahan yang makin demokratis.

Amandemen UUD 1945 yang menjadi refleksi semangat baru dalam penyelenggaraan pemerintahan, dilakukan dalam empat tahapan. Hasil amandemen UUD 1945, sebagai berikut : (a) Perubahan Pertama ditetapkan oleh MPR pada tanggal 9 Oktober 1999. Pasal-pasal UUD 1945 yang dilakukan perubahan adalah: Pasal 5 ayat (1), Pasal 7, Pasal 9, Pasal 13 ayat (2), Pasal 14, Pasal 15, Pasal 17 ayat (2) dan (3), Pasal 20 dan Pasal 21. (Menurut Suwoto perubahan pertama UUD 1945 ini menghasilkan perubahan wewenang (cetak miring penulis)membuat Undang -undang. Lebih lanjut dijelaskan bahwa: "Wewenang membuat Undang-undang yang berdasarkan Pasal 5 ayat (1) berada di Presiden, diubah menjadi wewenang DPR. Proses pembuatan UU harus ditandatangani oleh Presiden selaku Kepala Pemerintahan dan DPR serta harus disahkan oleh Presiden selaku Kepala Negara....") (Suwoto Mulyosudarmo, tanpa tahun, halaman;3); (b) Perubahan Kedua ditetapkan oleh MPR pada tanggal 18 Agustus 2000. Pasalpasal UUD 1945 yang dilakukan perubahan adalah : Pasal 18, Pasal 18A, Pasal 18 B, Pasal 19, Pasal 20 ayat (5), Pasal 20 A, Pasal 22 A, Pasal 22 B, Bab IXA, Pasal 25 E, Bab X, Pasal 26 ayat (2) dan ayat (3), Pasal 27 ayat (3), Bab XA, Pasal 28 A, Pasal 28 B, Pasal 28 C, Pasal 28 D, Pasal 28 E, Pasal 28 F, Pasal 28 G, Pasal 28 H, Pasal 28 I, Pasal 28 J, Bab XII, Bab XV, Pasal 36 A, Pasal 36 B, dan Pasal 36 C; (c)Perubahan Ketiga ditetapkan oleh MPR pada tanggal 9 November 2001. Pasal-pasal UUD 1945 yang dilakukan perubahan adalah : Pasal 1 Ayat (2) dan (3); Pasal 3 Ayat (1), (3), dan (4); Pasal 6 Ayat (1) dan (2); Pasal 6A Ayat (1), (2), (3), dan (5); Pasal 7A; Pasal 7B Ayat (1), (2), (3), (4), (5), (6), dan (7); Pasal 7C; Pasal 8 Ayat (1) dan (2); Pasal 11 Ayat (2) dan (3); Pasal 17 Ayat (4); Bab VIIA, Pasal 22C Ayat (1), (2), (3), dan 
(4); Pasal 22D Ayat (1), (2), (3), dan (4); Bab VIIB, Pasal 22E Ayat (1), (2), (3), (4), (5), dan (6); Pasal 23 Ayat (1), (2), dan (3); Pasal 23A; Pasal 23 C; Bab VIIIA, Pasal 23E Ayat (1), (2), dan (3); Pasal 23F Ayat (1) dan (2); Pasal 23G Ayat (1) dan (2); Pasal 24 Ayat (1) dan (2); Pasal 24A Ayat (1), (2), (3), (4), dan (5); Pasal 24B Ayat (1), (2), (3), dan (4); Pasal 24C Ayat (1), (2), (3), (4), (5), dan (6); (d)Perubahan Keempat ditetapkan oleh MPR pada tanggal 10 Agustus 2002. Pasal-pasal UUD 1945 yang dilakukan perubahan adalah : Pasal 2 ayat (1); Pasal 6A Ayat (4); Pasal 8 Ayat (3); Pasal 11 Ayat (1); Pasal 16; Pasal 23B; Pasal 23D; Pasal 24 Ayat (3); Bab XIII, Pasal 31 Ayat (1), (2), (3), (4), dan (5); Pasal 32 Ayat (1) dan Ayat (2); Bab XIV,Pasal 33 Ayat (4) dan Ayat (5); Pasal 34 Ayat (1), (2), (3), dan (4); Pasal 37 Ayat (1), (2), (3), (4), Dan (5); Aturan Peralihan Pasal I, II, dan III; Aturan Tambahan Pasal I dan Pasal II.

Perkembangan produk undangundang, juga menunjukkan arah yang perubahan yang sejalan dengan keinginan reformasi. Produk legislasi secara khusus merespon berbagai kebutuhan pengaturan yang berkait dengan penataan HAM, Hak-hak Politik dan Kelembagaan Negara. Rinciannya sebagai berikut : (a)Undang-undang Nomor 39 Tahun 1999 tentang Hak Asasi
Manusia; (b)Undang-undang Nomor 26 Tahun 2000 tentang Peradilan HAM; (c)Undang-undang Nomor 2 Tahun 1999 tentang Partai Politik diganti dengan UU No. 31 tahun 2002; (d)Undang-undang Nomor 12 Tahun 2003 Pemilihan Umum; (e)Undang-undang Nomor 22 Tahun 2003 tentang SUSDUK MPR, DPR, DPD dan DPRD; (f)Undangundang Nomor 23 Tahun 2003 tentang Pemilihan Umum Presiden dan Wakil Presiden; (g)Undang-undang Nomor 22 Tahun 1999 tentang Pemerintahan Daerah diganti dengan Undang-undang No. 32 Tahun 2004; (h)Undang-undang No. 24 Tahun 2003 tentang Mahkamah Konstitusi; (i)Undang-undang No. 4 Tahun 2004 tentang Kekuasaan Kehakiman; (j)Undang-undang No. 5 Tahun 2004 tentang Mahkamah Agung; (k)UU No. 20 Tahun 2004 tentang Komisi Yudisial.

\section{PENUTUP}

Berdasar paparan yang terurai di atas, maka dapat disimpulkan hal-hal sebagai berikut : (a)Hukum sebagai sebuah produk kekuasaan, tidak dapat dilepaskan dari pada konteks bagaimana kekuasaan itu dijalankan; (b)Memahami maksud dan tujuan berbagai produk hukum, maka tidak dapat dilepaskan pada sejarah pembentukannya; (c)Substansi aturan hukum selalu merupakan 
refleksi dari kemauan politik dari penguasa yang dominan pada masanya.

\section{DAFTAR PUTAKA}

Abdulgani, Ilmu Hukum dalam Revolusi, Badan Perbit Prapanca, tt.

Ahmad Sodiki,(20001). Pembaharuan Hukum Pertanahan Nasional, Dalam Rangka Penguatan Agenda Landreform, dalam kumpulan tulisan Prinsip-prinsip Reforma Agraria, Jalan Penghidupan dan Kemakmuran Rakyat, Cet. I., Lapera Pustaka Utama, Yogyakarta

Ball, John, (1982). Indonesian Legal History 1602-1848, Oughtershaw, Sydney

, (1984). Indonesian Legal History British West Sumatra, 1685-1825, Oughtershaw, Sydney

Berman, J. Harold, (1995). Law and Revolution, The Formation of the Western Legal Tradition, Harvard University Press, Cambridge, Massachusetts

Bruggink, J.J.H. (1999). Refleksi Tentang Hukum, alih bahasa, Bernard Arief Sidharta, Citra Aditya Bakti, Bandung

Charles Sampford, (1989). The Disorder of Law, A Critique of Legal Theory, Basil Blackwell Inc. New York

Freeman, Lloyd, (1985). Introduction to Jurisprudence, Lord Lloyd Hampstead Oc, University of London
Friedmann, W, (1990). Teori dan Filsafat Hukum, alih bahasa oleh Muhamad Arifin, Buku II, Raja Grafindo Persada

Hadjon, M. Phlipus, (1996). Prospek Hukum dalam Era Globalisasi, Surabaya

Indria Samego et.al, (1998). Bila ABRI Menghendaki, Mizan Pustaka, Bandung

Nisbit, John, Megatern 2000, edisi revisi, Warta Ekonomi, No. 01/1990

Paton, G.W. (1972). A Tex book of Jurisprudence, Fourth Edition

Philippe Nonet dan Philip Selznick, (1978). Law and Society in Tradition, Toward Responsive Law, Harper \& Row, Publishers, New York

Rahardjo, Satjipto, (1986). Hukum dalam Prespektif Sejarah dan Perubahan Sosial, dalam Pembangunan Hukum dalam Prespektif Politik Hukum Nasional, Editor Artidjo Alkostar dan Soleh Amin, Rajawali, Jakarta

Santos, Boaventura De Sousa, (1995). Toward A New Common Sense, Law Science and Politics in the Paradigmatic Transition, Routledge, Newyork

Sidharta, Arief, Bernard, (2000). Refleksi tentang Struktur Ilmu Hukum, Mandar Maju, Bandung

Simanjuntak, (1997). Marsilam, Pandangan Negara Integralistik, 
Cet II, Pustaka Utama Grafiti, Jakarta

Suwoto Mulyosudarmo, "Refleksi Hukum tentang Putusan Sidang Umum MPR 1999 dan Sidang Tahunan MPR 2000”, Makalah, tanpa tahun, halaman 3

Soetandyo Wignjosoebroto, (1998).

Dari Hukum Kolonial ke Hukum Nasional, Raja Grafindo Persada, Ed. I., Cet. I, Jakarta 